\title{
ResearchArticle
}

\section{Effect of Lipo-chitooligosaccharides on seed germination, growth, vigour and biochemical changes in soybean seedling}

\author{
V. SUGANYA, G. VELU AND P. JEYAKUMAR
}

\section{SUMMARY}

The bacterium-to-plant signal, lipo-chitooligosaccharides (LCOs) or Nod factor induces cell division and enhances seed germination. The experiment was conducted to test the efficacy of LCO on soybean seed germination and seedling growth under room temperature by roll towel method. Different concentrations of LCO were used for seed treatment along with microbial inoculum and biocontrol agents as a control. Among the treatments, concentration of LCO @ 1.8 and $3.6 \mathrm{ml} / \mathrm{kg}$ of seed performed better compared to other treatments. The results revealed that treating with LCO could influence soybean seed germination and growth of seedlings.

Key Words : Lipo-chitooligosaccharides (LCOs), Soybean, Seed germination

\begin{abstract}
How to cite this article : Suganya, V., Velu, G. and Jeyakumar, P. (2016). Effect of Lipo-chitooligosaccharides on seed germination, growth, vigour and biochemical changes in soybean seedling. Internat. J. Plant Sci., 11 (2): 244-248, DOI: 10.15740/HAS/IJPS/11.2/ 244-248.
\end{abstract}

Article chronicle : Received : 02.02.2016; Revised : 21.04.2016; Accepted : 03.06.2016

\footnotetext{
$\longrightarrow$ MEMBERS OF THE RESEARCH FORUM

Author to be contacted :

V. SUGANYA, Department of Crop Physiology, Tamil Nadu Agricultural University, COIMBATORE (T.N.) INDIA
}

Address of the Co-authors:

G. VELU AND P. JEYAKUMAR, Department of Crop Physiology, Tamil Nadu Agricultural University, COIMBATORE (T.N.) INDIA 